\title{
Perangkat Perkuliahan Terpadu Berbasis KPS untuk Meningkatkan Kompetensi Mahasiswa Pendidikan Fisika Mengembangkan Lembar Kerja Siswa
}

\author{
Wirda Nilawati $^{\text {a) }}$, Desnita ${ }^{\text {b) }}$, Nurdi Akbar ${ }^{\mathrm{c})}$ \\ Progran Studi Pendidikan Fisika FMIPA UNJ \\ Email: ${ }^{a)}$ wirda_nilawati_63@gmail.com, b) desywaznadil@gmail.com, \\ c)nurdi.akbar@gmail.com
}

\begin{abstract}
Developing Student Worksheet is one of the competences that must be mastered by Physics Education Student of FMIPA Universitas Negeri Jakarta. An integrated lecture tool has been developed to train students' writing competencies in the Physics Worksheet. This development research applies the ASSURE model. Lecture devices have been tested against physics education students. Students give very good appreciation to the lecture, by giving average score equal to 83.97. Students' performance in preparing the Student Worksheet physics subjects is also very good, which is shown by the average of student performance compiled the Subject Student Worksheet 84.52. Based on the results of testing the use of educational tools to students of education students FMIPA Universitas Negeri Jakarta showed that the lecture tools are worthy to be used as teaching materials.
\end{abstract}

Keywords: Integrated lecturing tools, KPS, Student Worksheet.

\begin{abstract}
Abstrak
Mengembangkan Lembar Kerja Siswa merupakan salah satu kompetensi yang harus dikuasai oleh Mahasiswa Pendidikan Fisika FMIPA UNJ. Telah dikembangkan perangkat perkuliahan terpadu untuk melatih kompetensi mahasiswa menulis Lembar Kerja Siswa mata pelajaran fisika. Penelitian pengembangan ini menerapkan model ASSURE. Perangkat perkuliahan sudah diujicoba terhadap mahasiswa pendidikan fisika. Mahasiswa memberikan apresiasi sangat baik terhadap perangkat perkuliahan, dengan memberikan skor rerata sebesar 83,97. Kinerja mahasiswa menyusun Lembar Kerja Siswa mata pelajaran fisika juga sangat baik, yang ditunjukan oleh rerata nilai kinerja mahasiswa menyusun Lembar Kerja Siswa mata pelajaran sebesar 84,52. Berdasarkan hasil ujicoba penggunaan perangkat pekuliahan terhadap mahasiswa pendidikan mahasiswa FMIPA UNJ menunjukan bahwa perangkat perkuliahan terpadu layak digunakan sebagai bahan ajar.
\end{abstract}

Kata-kata Kunci: Perangkat Perkuliahan Terpadu, KPS, Lembar Kerja Siswa. 


\section{PENDAHULUAN}

Salah satu kompetensi yang harus dikuasai oleh guru profesional adalah kompetensi pedagogik, hal ini sesuai dengan PP No.19 tahun 2005 dalam Adnan Hakim (2015), "Teaching Professional in carrying out their duties have various competence required in transferring knowledge to their students include pedagogical competence, personal competence, professional competence, and social competence." Terdapat sejumlah sub kompetensi dalam lingkup kompetensi pedagogik, menurut Adnan, "Components included in the pedagogical competency, namely (1) controls the characteristics of least from the physical aspect, the spiritual moral, social, cultural, emotional and intellectual, (2) control of learning theories and principles of learning that educates; (3) develop curriculum related to the subject matter; (4) conducting educational learning; (5) utilize information and communication technology for the sake of learning; (6) facilitate the development of potential learners to actualizse their potential; (7) communicate effectively, empathetic, and manner with the students; (8) conducting the assessment and evaluation processes and learning outcomes; (9) utilize the assessment and evaluation for the sake of learning; (10) take action to improve the quality of reflective learning." Seperti yang terlihat pada sub kompetensi empat bahwa salah satu sub kompetensi pedagogik adalah kemampuan untuk mengembangkan kurikulum, menyusun bahan ajar terkait materi pelajarannya. Dibutuhkan berbagai bentuk bahan ajar untuk memaksimalkan pencapaian kompetensi. Salah satu bahan ajar tersebut adalah Lembar Kegiatan Siswa (LKS).

Lembar Kerja Siswa (LKS) merupakan salah satu sumber belajar yang dapat dikembangkan oleh guru sebagai fasilitator dalam kegiatan pembelajaran. Menurut Surachman yang dikutip oleh Sumarni (2004: 15-16), LKS merupakan jenis hand out yang dimaksudkan untuk membantu siswa belajar secara terarah. Lembar Kerja Siswa selain sebagai media pembelajaran juga mempunyai beberapa fungsi yang lain, yaitu: 1) merupakan alternatif bagi guru untuk mengarahkan pengajaran atau memperkenalkan suatu kegiatan tertentu sebagai kegiatan belajar mengajar. 2) dapat digunakan untuk mempercepat proses pengajaran dan menghemat waktu penyajian suatu topik. 3) dapat untuk mengetahui seberapa jauh materi yang telah dikuasai siswa. 4) dapat mengoptimalkan alat bantu pengajaran yang terbatas. 5) membantu siswa dapat lebih aktif dalam proses belajar mengajar (Endang Widjajanti, 2008: 1-2).

Mahasiswa Pendidikan fisika adalah calon guru fisika pada tingkat SMP dan SMA. Sebagai calon guru mereka harus dilatih kompetensinya dalam menyusun LKS. Untuk menyusun sebuah LKS perlu penguasaan terhadap ilmu pengetahuan terkait materi pelajarannya, keterampilan proses sains dalam membangun kompetensi, dan pengetahuan pedagogik terutama tentang penyusunan bahan ajar, lebih fokus lagi RPP. Program studi fisika FMIPA UNJ memberikan bekal dalam bentuk pengetahuan fisika dalam sejumlah mata kuliah, seperti fisika dasar, fisika kuantum, dan fisika modern. Dan keterampilan ilmiah di laboratorium, seperti praktikum fisika dasar, praktikum fisika modern, dan manajemen laboratorium. Serta kompetensi pedagogik antara lain teori belajar dan pembelajaran, strategi pembelajaran sains, desain pembelajaran sains, dan penilaian pembelajaran sains, serta keterampilan mengajar.

Kemampuan menyusun LKS dilatih pada mata kuliah Pengembangan Bahan Ajar Fisika. Sesuai dengan fungsinya sebagai penuntun bagi siswa dalam melakukan kegiatan ilmiah dalam pembelajaran, LKS dapat berbentuk panduan berpikir ilmiah atau melakukan keterampilan motorik di laboratorium. Penggunaan LKS pada proses pembelajaran akan menambah pemahaman dan keterampilan siswa, dan model pembelajaran tersebut masuk ke dalam model pembelajaran hands on minds on. Model pembelajaran hands on minds on yaitu model pembelajaran siswa tidak hanya melihat dan mendengarkan guru menjelaskan, tetapi dalam pembelajaran ini siswa mengamati, melakukan dan mengidentifikasi secara langsung pada objek yang dipelajari. Model pembelajaran ini dapat membuat siswa mempunyai pengalaman langsung, sehingga dapat mengatasi masalah belajar siswa seperti sulit mengingat materi pelajaran (Euis Komariah Siswati, 2012: 34).

Dibutuhkan perangkat perkuliahan terpadu berbasis keterampilan proses sains, yang dapat memberikan pengalaman belajar kepada mahasiswa Pendidikan fisika; agar mereka mampu menyusun LKS pelajaran fisika menerapkan langkah ilmiah. Bahan ajar tersebut diharapkan dapat melatih kemampuan menyusun LKS secara mandiri. Mengingat pentingnya keterampilan proses sains dalam pembelajaran Fisika, maka salah satu upaya untuk melatihkan keterampilan proses sains 
mahasiswa adalah melalui pembelajaran dengan model inkuiri terbimbing (Putri Ayuningtyas, 2015: 638). Pembelajaran dengan metode Keterampiln Proses Sain (KPS) akan berjalan dengan baik jika ada dukungan fasilitas yang cukup. Fasilitas tersebut meliputi: laboratorium fisika (alat dan bahan lengkap), buku pegangan siswa, Lembar Kerja Siswa (LKS) dan buku/lembaran tuntunan belajar bagi siswa dan mengajar bagi guru untuk melakukan diskusi, praktikum, latihan penemuan hingga latihan inkuiri (Meita Widian Pangestika, 2013: 56).

\section{METODE PENELITIAN}

Setiap penelitian yang dilakukan memiliki tujuan. Penelitian ini dilakukan dengan tujuan menghasilkan perangkat perkuliahan terpadu berbasis KPS, yang layak digunakan sebagai bahan ajar pada mata kuliah Pengembangan Bahan Ajar Fisika. Dilakukan pada Program Studi Pendidikan Fisika FMIPA Universitas Negeri Jakarta, pada tahun 2016. Perangkat perkuliahan yang dikembangkan adalah silabus mata kuliah Pengembangan Bahan Ajar Fisika, Handout, Lembar Kegiatan Mahasiswa, dan Lembar Penilaian Kinerja Mahasiswa.

Kelayakan perangkat perangkat perkuliahan diukur menggunakan Teknik tes dan non tes berupa wawancara dan diskusi intensif dengan teman sejawat dari Program Studi Pendidikan Fisika. Ujicoba dilakukan terhadap mahasiswa Pendidikan Fisika yang terdaftar pada mata kuliah Pengembangan Bahan Ajar Fisika pada semester ganjil 2016/2017, berjumlah 36 orang. Data yang dikumpulkan dari mahasiswa berupa penilaian mahasiswa terhadap perangkat perkuliahan Pengembangan Bahan Ajar Fisika, berupa hand out, Lembar Kegiatan Mahasiswa, dan Lembar Penilaian Kinerja Mahasiswa; serta kinerja mahasiswa mengembangan bahan ajar fisika, salah satunya adalah Lembar Kerja Siswa untuk mata pelajaran fisika.

\section{HASIL DAN PEMBAHASAN}

\section{Produk Penelitian}

Sesuai dengan rencana yang telah disusun, penelitian ini menghasilkan produk berupa perangkat perkuliahan untuk mata kuliah Keterampilan Mengajar pada Program Studi Pendidikan Fisika. Produk yang dihasilkan disajikan pada TABEL 1.

TABEL 1. Produk Penelitian

\begin{tabular}{|c|c|c|c|c|}
\hline \multirow[b]{2}{*}{ No } & \multirow[b]{2}{*}{ Jenis Produk } & \multicolumn{3}{|c|}{ Materi } \\
\hline & & $\begin{array}{c}\text { Desain Bahan Ajar } \\
\text { Fisika }\end{array}$ & $\begin{array}{c}\text { Pengembangan } \\
\text { Modul Fisika }\end{array}$ & $\begin{array}{c}\text { Pengembangan LKS } \\
\text { Fisika }\end{array}$ \\
\hline 1 & Silabus mata kuliah & \multicolumn{3}{|c|}{ Semua materi ajar pada mata kuliah Pengembangan Bahan Ajar Fisika } \\
\hline 2 & Hand Out & $\sqrt{ }$ & $\sqrt{ }$ & $\sqrt{ }$ \\
\hline 3 & $\begin{array}{l}\text { Lembar Kegiatan } \\
\text { Mahasiswa }\end{array}$ & $\sqrt{ }$ & $\sqrt{ }$ & $\sqrt{ }$ \\
\hline 4 & $\begin{array}{l}\text { Lembar Penilaian } \\
\text { Kinerja Mahasiswa }\end{array}$ & $\sqrt{ }$ & $\sqrt{ }$ & $\sqrt{ }$ \\
\hline
\end{tabular}

\section{Validasi Sejawat}

Semua produk penelitian sudah divalidasi dan diujicoba terbatas terhadap satu rombongan belajar yang terdiri dari 36 orang. Validasi dilakukan dengan teman sejawat pada Program Studi Pendidikan Fisika FMIPA Universitas Negeri Jakarta. Data validasi sejawat berupa data kualitatif. Data dikumpulkan dengan teknik penelitian kualitatif, dengan melakukan diskusi intensif beberapa kali, termasuk di dalamnya diskusi saat workshop kurikulum. kegiatan, masukan, dan produk penelitian yang dihasilkan dan direvisi berdasarkan masukan teman sejawat, secara singkat disajikan pada TABEL 2. 
TABEL 2. Tabel Data Validasi Sejawat

\begin{tabular}{llll}
\hline No & Topik Bahasan & Masukan Sejawat & Produk \\
\hline 1 & Silabus Mata Kuliah & Sebaiknya jelas dan tegaskan batasan & Silabus mata kuliah \\
& $\begin{array}{l}\text { Pengembangan Bahan } \\
\text { Ajar Fisika. }\end{array}$ & $\begin{array}{l}\text { isi, strategi, penugasan, dan produk } \\
\text { mata kuliah, sehingga tidak terjadi } \\
\text { overlapping dengan mata kuliah lain. }\end{array}$ & Pengembangan Bahan Ajar \\
& & Sebaiknya disusun berbasis & Hand out, Lembar Kegiatan \\
\hline 2 & Perangkat perkuliahan & keterampilan proses sains dan & Mahasiswa, dan Lembar \\
& Pengembangan Bahan & memberikan pengalaman yang dapat & Penilaian Kinerja Mahasiswa \\
& melatih mengembangkan bahan ajar & berbasis keterampilan proses \\
& & fisika yang digunakan pada & sains untuk materi membuat \\
& & pembelajaran fisika pada tingkat SMA. & desain bahan ajar, menulis \\
& & Sesuai dengan tugas seorang guru & modul, dan menulis Lembar \\
& fisika yang professional. & Kegiatan Siswa untuk pelajaran \\
& & & fisika SMA.
\end{tabular}

\section{Ujicoba Produk}

Telah dilakukan ujicoba terhadap produk penelitian. Selain silabus telah diujicobakan terhadap satu rombongan belajar Pendidikan Fisika FMIPA UNJ yang terdiri dari tigapuluh enam orang mahasiswa. Produk yang diujicoba terhadap mahasiswa adalah handout, Lembar Kegiatan Mahasiswa, dan Lembar Penilaian Kinerja Mahasiswa untuk materi membuat desain bahan ajar, menulis modul, dan menulis Lembar Kegiatan Siswa mata pelajaran Fisika SMA.

Data hasil ujicoba berupa (1) penilaian mahasiswa terhadap perangkat perkuliahan yang dikembangkan, dikumpulkan menggunakan angket, mencakup tiga aspek, yaitu materi/ isi, penyajian, dan bahasa, yang terdiri dari empatbelas butir, dengan empat kategori penilaian 1, 2, 4, dan 5; (2) kemampuan mahasiswa menulis desain bahan ajar, menulis modul, dan menulis Lembar Kegiatan Mahasiswa yang jumlah butirnya sesuai dengan indikator untuk masing-masing materi perkuliahan dan jumlah poin aktivitas belajar dan target belajar, pada masing-masing materi kuliah.

Data respon atau penilaian mahasiswa terhadap produk bahan ajar mata kuliah Pengembangan Bahan Ajar, berkisar antara 71,43 sampai 98,57, dengan rerata 83,97. Sebaran respon terhadap masing-masing butir disajikan pada GAMBAR 1.

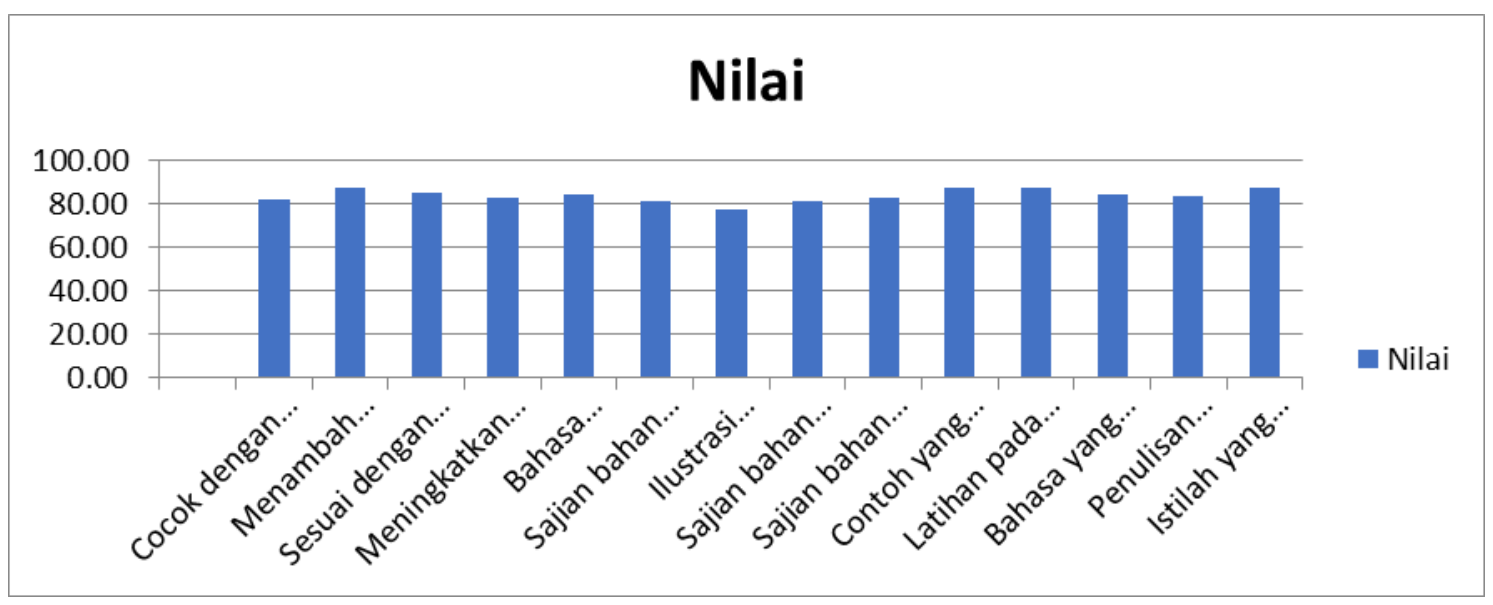

GAMBAR 1. Distribusi respon mahasiswa terhadap perangkat kuliah

Berdasarkan diagram pada GAMBAR 1 terlihat bahwa tiga belas dari empat belas butir penilaian, direspon atau diapresiasi oleh mahasiswa dengan sangat baik, dan satu butir direspon dengan memberikan penilaian baik.

Penilaian kinerja mahasiswa menggunakan hand out, Lembar kegiatan Mahasiswa dan Lembar Penilaian Kinerja Mahasiswa, dikumpulkan menggunakan instrumen penilaian kinerja. Dalam skala 1-100, nilai kinerja mahasiswa berkisar antara 80 - 100 untuk desain bahan ajar fisika, 83 - 93 untuk penulisan modul fisika, dan 84 - 95 untuk penulisan Lembar Kegiatan Siswa mata pelajaran fisika SMA. Rerata nilai mahasiswa untuk ke tiga produk disajikan pada GAMBAR 2. 


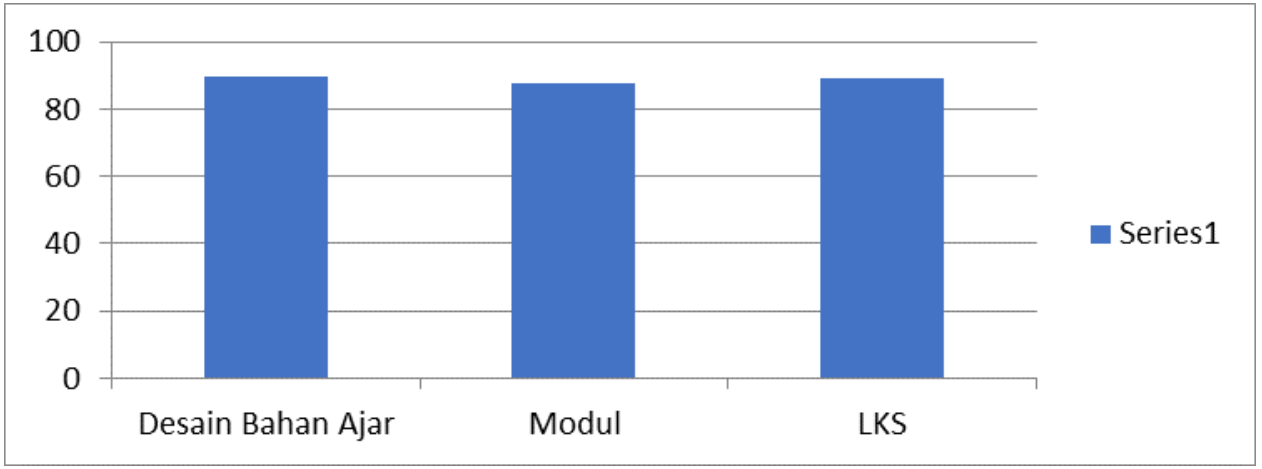

GAMBAR 2. Nilai kinerja mahasiswa mengembangkan bahan ajar fisika SMA.

Distribusi frekuensi nilai kinerja mahasiswa mengembangkan mahan ajar fisika SMA dapat dilihat pada gambar 5 ,

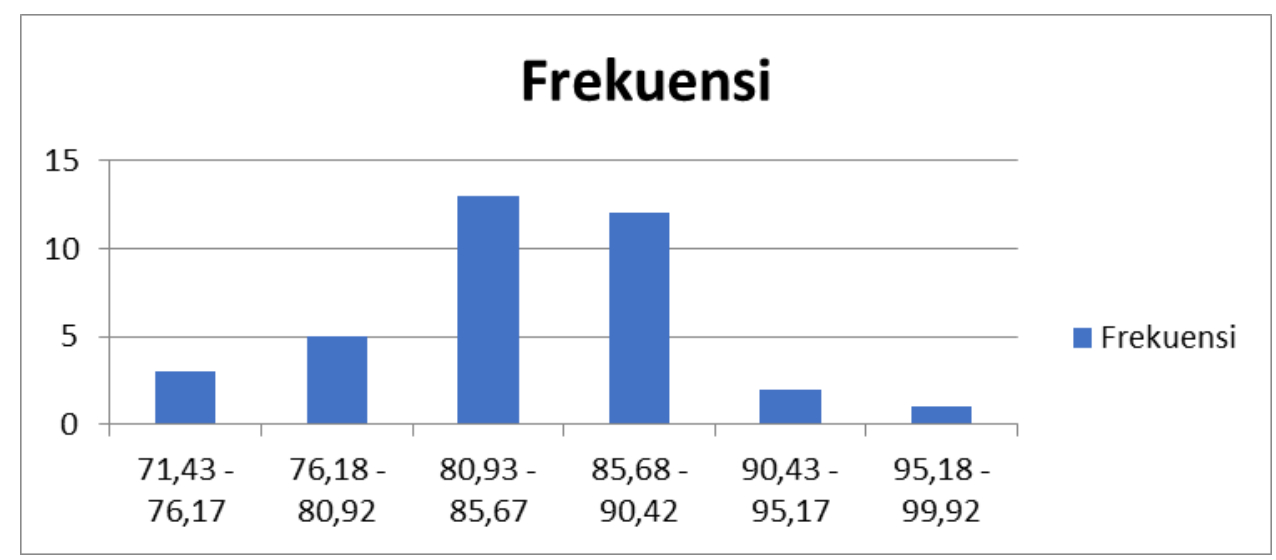

GAMBAR 5. Distribusi frekuensi nilai mahasiswa mengembangkan bahan ajar fisika.

Terlihat dari distribusi frekuensi nilai mahasiswa, bahwa kinerja mahasiswa mengembangkan bahan ajar fisika berdistribusi normal. Berkisar dari rentangan baik dan sangat baik. Puncak grafik berada pada kisaran 80,93 - 90,42, dengan kategori penilaian sangat baik. Hasil ini sejalan dengan hasil penilaian mahasiswa terhadap perangkat perkuliahan.

\section{Pembahasan}

Penelitian ini dilakukan dengan tujuan menghasilkan perangkat perkuliahan Pengembangan bahan Ajar Fisika berbasis keterampilan proses sains. Dimana harapan peneliti adalah penggunaan produk penelitian ini oleh mahasiswa tidak hanya berdampak terhadap kemampuan mahasiswa dalam menulis bahan ajar fisika berbasis keterampilan proses sains. Lebih dari itu produk penelitian ini memberikan pengalaman belajar layaknya didapat oleh seorang calon guru dalam mengembangkan bahan ajar fisika SMA.

Pembuatan perangkat perkuliahan ini dimulai dengan meminta masukan dari tim dosen kelompok mata kuliah Dasar Kependidikan Program Studi Pendidikan Fisika FMIPA UNJ. Telah dilakukan beberapa kali diskusi oleh tim MKDK pendidikan fisika. Diskusi dimulai dengan mengkaji KKNI Pendidikan fisika yang direkomendasikan oleh Asosiasi Program Studi Pendidikan Fisika Indonesia. Dimana KKNI tersebut disusun berdasarkan keterampilan mengajar abad 21 dengan pendekatan keterampilan proses sains.

Informasi yang berhasil kami serap kami jadikan sebagai masukan atau rujukan dalam mengembangkan semua produk penelitian ini. Sehingga cakupan materi, strategi, tagihan/ penugasan, dan produk mata kuliah sudah mendapatkan masukan dan mempertimbangan keterpenuhan kompetensi dan menghindari overlapping antar mata kuliah dalam kelompok MKDK. 
Walaupun teman sejawat tidak memberikan masukan berupa penilaian kuantitatif. Masukan terhadap silabus dan RPS mata kuliah Keterampilan Mengajar Fisika yang diberikan dapat dianggap sebagai validasi sejawat. Karena diskusi dengan teman sejawat terjadi sebelum pembuatan perangkat perkuliahan, pada saat, dan setelah draft perangkat tersebut disusun. Sehingga produk yang diujicobakan kepada mahasiswa sudah merupakan perangkat hasil validasi sejawat.

Modul, Lembar Kerja, dan Lembar Penilaian Kinerja Mahasiswa sebagai bahan ajar yang dikembangkan di dalam mata kuliah ini merupakan bahan ajar mandiri, saling bersinergi mengarahkan dan menuntun mahasiswa menggali pengetahuan dan keterampilan menulis bahan ajar, berlatih mengembangkan perangkat pembelajaran fisika berbasis keterampilan proses sains, dan berlatih mengajar fisika sesuai rencana yang telah disusun.

Perangkat perkuliahan Pengembangan Bahan Ajar Fisika yang dikembangkan ini memberikan arahan kepada mahasiswa tentang aktivitas belajar apasaja yang perlu mereka lakukan secara mandiri dan aktivitas mana pula yang dilakukan secara berkolaborasi. Apa target yang harus dicapai pada setiap aktivitas belajar, dan bagaimana menilai secara mandiri hasil yang mereka peroleh. Hasil belajar mahasiswa tersebut tidak hanya pengetahuan dan keterampilan, namun juga pengalaman layaknya pekerjaan seorang guru fisika serta berkolaborasi dengan sesama mahasiswa.

Pengalaman kuliah yang mereka alami menggunakan perangkat perkuliahan ini, yang terdiri dari (1) membaca hand out, (2) mengerjakan latihan menyusun perangkat pembelajaran fisika SMA dan memeriksa ketepatan latihan secara mandiri, dalam kerja kelompok, (3) mengerjakan latihan personal berupa menulis desain, modul, dan LKS fisika SMA dan melakukan penilaian secara mandiri menggunakan lembar penilaian kinerja.

Penilaian sangat baik yang diberikan oleh mahasiswa terhadap perangkat perkuliahan yang digunakan, tidaklah berlebihan. Bahkan ada mahasiswa yang memberikan saran supaya perangkat perkuliahan ini di up load sehingga bisa digunakan oleh guru fisika. Karena mereka sangat merasakan kebermanfaatannya dalam mengontrol secara mandiri kinerja guru fisika, khususnya dalam menyusun perangkat pembelajaran dan praktik pembelajaran. Mereka juga berharap produk perkuliahan ini bisa dilengkapi dan diterbitkan, supaya bisa dimanfaatkan banyak pendidik fisika di mana saja di seluruh Indonesia.

Mahasiswa bisa memberikan masukan seperti yang disampaikan di atas, karena tim peneliti memilih mahasiswa yang baru saja selesai melaksanakan Praktik mengajar di sekolah, jadi mereka sudah kenal kompetensi dan kebutuhan guru akan bahan ajar seperti yang dikembangkan ini. Pada saat menyerahkan perangkat perkuliahan tim peneliti mengingatkan mahasiswa supaya mengisi angket setelah menggunakan perangkat perkuliahan. Juga dipesankan kepada mereka supaya mengisi secara objektif, karena hanya dengan demikian akan didapatkan perangkat perkuliahan yang bermanfaat.

Penilaian secara kuantitatif dan saran yang diberikan oleh mahasiswa mememberikan indikasi bahwa perangkat perkuliahan hasil pengembangan dinantikan kehadirannya, dirasakan manfaatnya, dan memberikan pengalaman belajar layaknya bagaimana seorang calon guru belajar dengan demikian dapat dikatakan bahwa perangkat perkuliahan hasil pengembangan sangat bermanfaat dan tepat guna, serta layak digunakan sebagai bahan ajar bagi mahasiswa pendidikan fisika.

\section{SIMPULAN}

Mengacu pada hasil dan pembahasan yang telah disampaikan, dapat disimpulkan bahwa: (1) Semua perangkat perkuliahan yang dihasilkan pada penelitian ini layak digunakan sebagai bahan ajar pada mata kuliah Keterampilan mengajar Fisika; (2) Penggunaan perangkat perkuliahan hasil pengembangan oleh mahasiswa dapat meningkatkan kompetensi mahasiswa mengembangkan bahan ajar fisika. 


\section{UCAPAN TERIMAKASIH}

Terlaksananya penelitian ini tidak terlepas dari dukungan pimpinan baik pada tingkat universitas, fakultas, maupun program studi. Oleh sebab itu melalui lembar ini kami menghaturkan terima kasih kepada Bapak Rektor UNJ dan jajarannya, Bapak Dekan UNJ beserta jajarannya, serta Bapak Ketua Program Studi Pendidikan Fisika

\section{REFERENSI}

Ayuningtyas, Putri, dkk. 2015. Pengembangan Perangkat Pembelajaran Fisika dengan Model Inkuiri Terbimbing untuk Melatihkan Keterampilan Proses Sains Siswa SMA pada Materi Fluida Statis. Surabaya: Pendidikan Sains Pascasarjana Universitas Negeri Surabaya, Vol 4, No. 2.

Pangestika, Meita Widian, dkk. 2013. Pengembangan Lembar Kerja Siswa Berbasis Keterampilan Proses Sains pada Kompetensi Dasar Menyelidiki Sifat-Sifat Zat Berdasarkan Wujudnya dan Penerapannya dalam Kehidupan Sehari-Hari. Lampung: Jurnal Pembelajaran Fisika, Vol 1, No1.

Siswati, Euis Komariah, dkk. 2012. Model Hands On Minds On dengan Bantuan Media Asli pada Materi Spermatophyta. Semarang: Unnes Journal of Biology Education.

Widjajanti, Endang. 2008. Kualitas Lembar Kerja Siswa. Yogyakarta: Jurusan Kimia FMIPA UNY. 
